\title{
Developmental stages and fecundity of Lepeophtheirus simplex (Copepoda: Caligidae) parasitic on bullseye puffer fish (Sphoeroides annulatus)
}

\author{
Francisco Neptalí Morales-Serna ${ }^{1}$, Ana Inés Rivas-Salas ${ }^{1}$, Samuel Gómez $^{2}$ and Emma Josefina Fajer-Ávila ${ }^{1}$ \\ ${ }^{1}$ Centro de Investigación en Alimentación y Desarrollo, Unidad Mazatlán en Acuicultura y Manejo Ambiental, Sinaloa, México; \\ ${ }^{2}$ Universidad Nacional Autónoma de México, Instituto de Ciencias del Mar y Limnología, Unidad Académica Mazatlán, Sinaloa, \\ México
}

\begin{abstract}
Lepeophtheirus simplex Ho, Gómez et Fajer-Avila, 2001 is a parasite of Sphoeroides annulatus (Jenyns), an economically important fish species, with potential for aquaculture, in northwestern Mexico. The goal of this study was to describe the developmental stages under experimental conditions and seasonal fecundity of this parasite on wild fish. There are two naupliar, one copepodid, two chalimus and two pre-adult stages preceding the adult of $L$. simplex. The results support previous findings, which point out that the life cycle of the caligid copepods includes only six post-naupliar stages. The generation time from egg extrusion to adult for $L$. simplex was approximately 10 days at $22{ }^{\circ} \mathrm{C}$. The body length of the ovigerous females ranged between 2.2 and $4.1 \mathrm{~mm}$, and its fecundity between 12 and 36 eggs per string. Fecundity was negatively correlated with the egg size and positively correlated with the egg string length. Our data did not reveal significant differences in fecundity among sampling months, but ovigerous females were significantly larger in March (when water temperature was $22^{\circ} \mathrm{C}$ ) than in June and July (when water temperature was $30^{\circ} \mathrm{C}$ ). To some extent, our fecundity results contrast with those found in species of sea lice from higher latitudes. Undoubtedly, biological information on different species of sea lice from different environmental conditions will enhance our understanding of their infection strategies and will be valuable, given the increasing interest in marine fish farming in Mexico.
\end{abstract}

Keywords: Siphonostomatoida, life cycle, sea louse, crustacean, Mexican Pacific, Tetraodontidae

The group of parasitic copepods usually known as 'sea lice' belongs to the family Caligidae Burmeister, 1835 (Copepoda: Siphonostomatoida). These crustaceans are very common parasites on marine fishes, with more than 450 known species (Dojiri and Ho 2013). With 124 species, Lepeophtheirus von Nordmann, 1832 is the second most species rich genus within the family, being outnumbered only by Caligus Müller, 1785 with more than 250 species (Walter and Boxshall 2014). In addition to their high biodiversity, sea lice have been widely known because some species are deleterious to fish cultured in marine or brackish water causing significant economic losses (Ho and Lin 2004, Johnson et al. 2004, Costello 2006, 2009).

To the best of our knowledge, the full life cycle is known only for 18 species of Caligidae, including 13 species of Caligus, namely C. centrodonti Baird, 1850; C. clemensi Parker et Margolis, 1964; C. curtus Müller, 1785; C. elongatus von Nordmann, 1832; C. epidemicus Hewitt, 1971; C. fugu (Yamaguti, 1936); C. latigenitalis Shiino, 1954; C. minimus Otto, 1821; C. orientalis Gusev, 1951; C. pageti Russell, 1925; C. punctatus Shiino, 1955; C. ro- tundigenitalis Yü, 1933; and C. spinosus Yamaguti, 1939, and five species of Lepeophtheirus, namely L. dissimulatus Wilson, 1905; L. elegans Gusev, 1951; L. hospitalis Fraser, 1920; L. pectoralis (Müller, 1776); and L. salmonis (Krøyer, 1837) (Ho and Lin 2004, Ohtsuka et al. 2009, Madinabeitia and Nagasawa 2011, Venmathi Maran et al. 2013). It is important to point out that Ohtsuka et al. (2009) originally described the developmental stages of Pseudocaligus fugu Yamaguti, 1936; however, the genus Pseudocaligus A. Scott, 1901 has recently been relegated to a junior synonym of Caligus by Dojiri and Ho (2013).

Undoubtedly, evidence of the developmental stages of more species of sea lice would provide a stronger comparative base and additional data to test the hypothesis concerning the life cycle complexity of the Caligidae, such as the number of stages during the post-naupliar phase (see Ohtsuka et al. 2009, Hamre et al. 2013, Venmathi Maran et al. 2013). Further, knowledge of the life cycle of sea lice is relevant for control strategies in aquaculture (González and Carvajal 2003, Ohtsuka et al. 2009). For instance, knowing the correct number of moults is essential if moult 
inhibitors are to be used effectively as chemotherapeutants (Hamre et al. 2013).

Knowledge of the fecundity of sea lice is required for understanding their population dynamics and to develop epidemiological models. According to Costello (2006), the abundance of sea lice depends, to some extent, on their intrinsic fecundity, which is significantly influenced by water temperature. Observations made on Caligus roggercresseyi Boxshall et Bravo, 2000 and L. salmonis have discovered that relatively low temperatures correlate with larger females, with longer egg strings and more eggs (Ritchie et al. 1993, Heuch et al. 2000, Bravo et al. 2013). Since these two species are distributed in temperate waters, the question arises whether the same trends are observable in sea lice from tropical or subtropical waters. In the context of aquaculture, this kind of information is necessary to assess what seasonal conditions are more favourable for sea louse fecundity and for planning and implementing pest management strategies (Bravo et al. 2013, González et al. 2013).

Lepeophtheirus simplex Ho, Gómez et Fajer-Avila, 2001 is a sea louse parasitising bullseye puffer Sphoeroides annulatus (Jenyns) (Tetraodontidae) from the northwestern coast of Mexico (Ho et al. 2001). This infection occurs all year round, but it is particularly higher during the warmest months (August to October) reaching a prevalence of about 90\% (Morales-Serna et al. 2011). Furthermore, L. simplex has been associated with skin pathology and mortality of S. annulatus reared in experimental tanks (Fajer-Ávila et al. 2008). Sphoeroides annulatus is an economically important fish; it is both a highly appreciated food in the region and exported in large quantities. Biotechnological research has revealed that $S$. annulatus has a good potential for aquaculture in Mexico (Chávez-Sánchez et al. 2008). We consider that more information about the biology of L. simplex is required. Here we describe the developmental stages, including the time of development, and the fecundity of this parasite.

\section{MATERIALS AND METHODS}

\section{Developmental stages}

Ovigerous females of Lepeophtheirus simplex were collected from body surface of Sphoeroides annulatus caught by hook and line in Teacapán lagoon $\left(22^{\circ} 33^{\prime} \mathrm{N} ; 105^{\circ} 45^{\prime} \mathrm{W}\right)$, Sinaloa State, Mexico in March 2003. Nauplii and infective copepodids were obtained from gravid sea lice incubated in $250 \mathrm{ml}$ PVC cylindrical containers (with two $7 \times 3 \mathrm{~cm}$ rectangular windows and the bottom covered with a $150 \mu \mathrm{m}$ net), which were suspended in a flow through 601 aquarium with aeration. The experiment was carried out in a constant temperature environment $\left(22 \pm 1^{\circ} \mathrm{C}\right)$ with filtered seawater (34\%) and constant aeration. Under the same water conditions described above, parasitic stages were obtained from fish (S. annulatus) cultured in the Centro de Investigación en Alimentación y Desarrollo (CIAD) at Mazatlán, Mexico. The body length and weight of fish averaged $9.4 \mathrm{~cm}$ and $23.5 \mathrm{~g}$, respectively. This experiment was performed using 22201 aquaria, with two fish and 50 copepodids per aquarium. Aeration was sus- pended for $4 \mathrm{~h}$ to allow copepodids to attach to the host. Once per day, fish were hand fed with $1 \mathrm{~g}$ of a commercial diet, and leftover food and faeces were removed. Starting $15 \mathrm{~h}$ post infection, fish were sacrificed periodically in order to collect juveniles of $L$. simplex, which were removed, fixed in $70 \%$ ethanol, cleared in lactophenol and observed with a Leica DMLB microscope. The temporal change in composition of developmental stages of L. simplex after infection was observed from the above material.

Copepods were counted and classified as first nauplius, second nauplius, copepodid, first chalimus, second chalimus, preadult I, pre-adult II and adult according to Hamre et al. (2013) and Venmathi Maran et al. (2013). Drawings and measurements were made from whole and dissected specimens with a Leica compound microscope equipped with phase contrast and a drawing tube. Measurements taken by ocular micrometre are in $\mu \mathrm{m}$ unless otherwise stated and presented in the text as the range followed by the mean and number of measurements (n) in parentheses. Terminology follows Boxshall (1990) and Huys and Boxshall (1991). Spines and setae are not distinguished in the setal formula given for chalimus I and II. In the copepodid and pre-adult stages, spines are given by Roman numerals and setae by Arabic numerals.

\section{Fecundity}

Wild fish were captured periodically, approximately every month, between February 2007 and February 2008, and between March and September 2013, in Santa María La Reforma lagoon $\left(25^{\circ} 10^{\prime} \mathrm{N} ; 108^{\circ} 20^{\prime} \mathrm{W}\right.$ and $\left.24^{\circ} 50^{\prime} \mathrm{N} ; 107^{\circ} 55^{\prime} \mathrm{W}\right)$, located on the Mexican Pacific coast (Sinaloa State). This region is typically characterised by two contrasting seasons during the year (a rainy and warm season from June to November, and a dry and relatively cold season from December to May). Sampling details, including environmental characteristics of the lagoon, were provided by Morales-Serna et al. (2011). Water temperature was recorded in each sampling month. Parasitic copepods collected were identified, counted, fixed in $70 \%$ ethanol and stored until observation. Body dimensions and reproductive effort of $L$. simplex were measured following González et al. (2012) and Bravo et al. (2013). Ovigerous females (OF) were measured in mm with an ocular micrometer at $10 \times$ on a Leica microscope. Total body length (excluding setae on caudal rami), egg string length, and total number of eggs per string of each OF were recorded. Fecundity was estimated based on the average number of eggs of the two strings. Mean length of egg strings was assessed as the average length of the two strings. The average egg length was calculated by dividing the egg string length by the number of eggs contained in the egg string. Infection levels were described in Morales-Serna et al. (2011); therefore, these parameters are not analysed herein.

Possible significant associations between variables were assessed with Spearman's rank order correlations. Differences in OF body length, egg string length, fecundity and average egg length between sampling months were evaluated with the Kruskal-Wallis test and Dunn's method as a posteriori test. These analyses were performed in SigmaStat 3.5 (Systat Software, Inc., San Jose, CA, USA). 

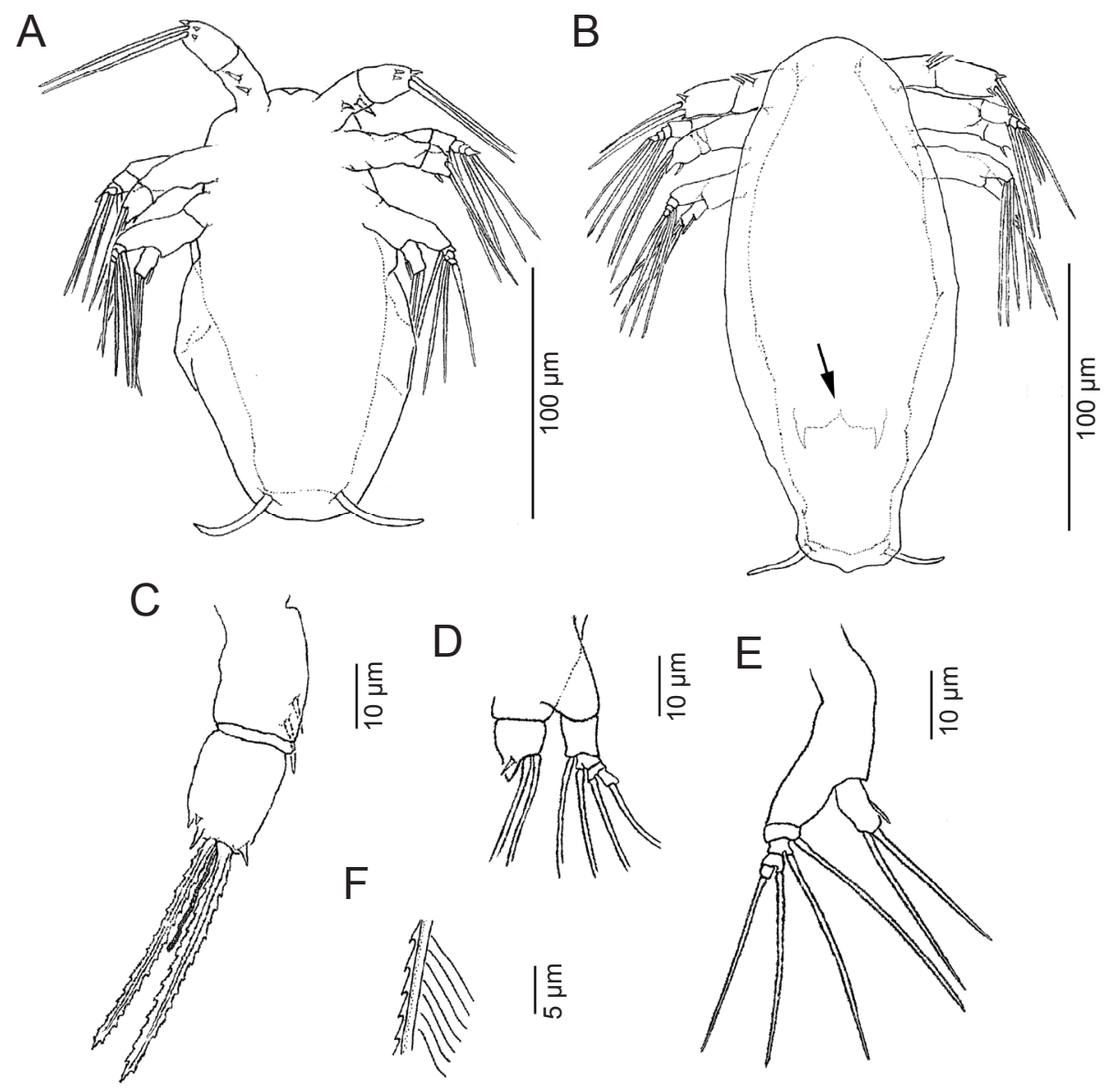

Fig. 1. Lepeophtheirus simplex Ho, Gómez et Fajer-Avila, 2001 from Sphoeroides annulatus. A - habitus, ventral, FN; B - habitus, dorsal (arrow showing anlage of maxilliped), SN; C - antennule, FN; D - antenna, FN; E - mandible, FN; F - ornamentation of setae on antenna and mandible, FN. Abbreviations: FN - first nauplius, $\mathrm{SN}-$ second nauplius.

\section{RESULTS}

\section{The developmental stages of Lepeophtheirus simplex}

\section{First nauplius}

Fig. 1A, C-E

Body 165-192 (173, $\mathrm{n}=53)$ long, ovoid, widest at midlength; without evident external segmentation (Fig. 1A). Nauplius eye present. Paired balancers located posterolaterally, curved outwards.

Antennule (Fig. 1C) two-segmented; proximal segment longest, with two marginal setae; distal segment separated from proximal segment by distinct ridged articulation; distal segment with four short spiniform elements subterminally around apex, plus two pinnate setae and one short aesthetasc terminally.

Antenna (Fig. 1D) biramous, with protopod indistinctly divided into coxa and basis; basis not separated from proximal segments of rami. Exopod five-segmented; second to fifth free segments each bearing one inner distal setae. Endopod two-segmented; second free segment produced distally into dentiform process, and with one short simple and two plumose setae terminally. Long setae on both rami with serrate outer and plumose inner margins (Fig. 1F).

Mandible (Fig. 1E) biramous; exopodal segments I-IV each bearing one seta similar to that on antenna. Endopod with single elongate free segment bearing two terminal plumose setae and one short inner naked seta proximally. Long setae on both rami with serrate outer and plumose inner margins (Fig. 1F).

\section{Second nauplius}

Fig. 1B

Body length: 207-218 (211, $\mathrm{n}=25)$ long, more slender than preceding stage; posterior end with tapering posterior process in mid-line (Fig. 1B). Antennule, antenna and mandible essentially as in preceding stage. Anlage of maxilliped first appearing in this stage, consisting of pair of slender, digitiform processes posteriorly-directed (Fig. arrowed in 1B).

\section{Copepodid}

Figs 2, 3

Body 614-662 (656, $\mathrm{n}=9)$ ) long. Cephalothorax incorporating first pedigerous somite, about 1.6 times as long as free postcephalothoracic somites and caudal rami combined (Fig. 2A); rostrum (Fig. 2B) weakly developed, triangular posteriorly-directed. Second pedigerous somite free, wider than long; third pedigerous somite with anlagen of leg 3 (arrowed in Fig. 2D); third free somite slightly smaller than preceding somite, unarmed; fourth somite (anal somite) with short caudal rami (Fig. 2D) each having single flaccid element (seta IV - derived from naupliar balancer - Ohtsuka et al. 2009) and five setae. 


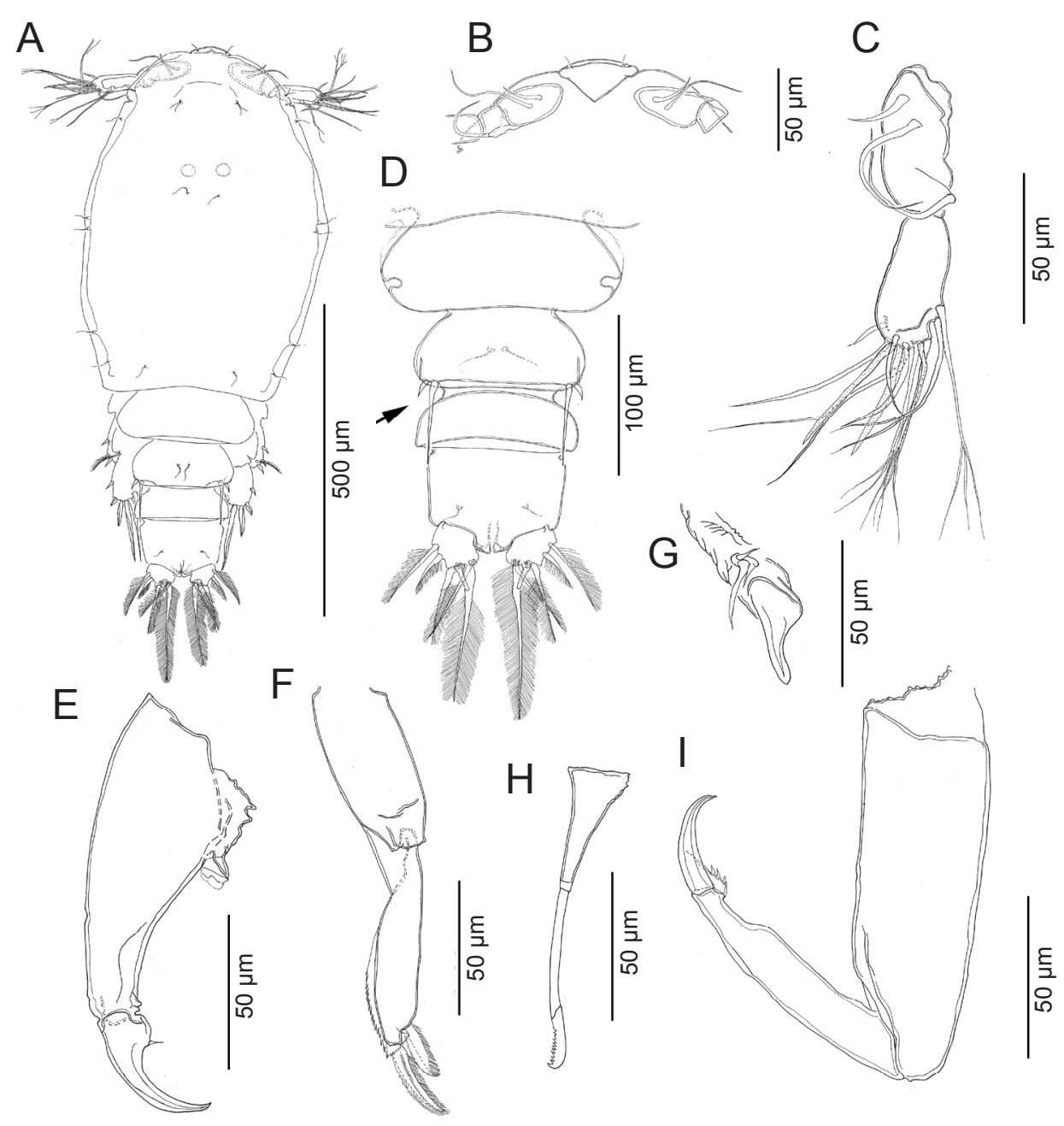

Fig. 2. Lepeophtheirus simplex Ho, Gómez et Fajer-Avila, 2001 from Sphoeroides annulatus. Copepodid: A - habitus, dorsal; B - rostrum; C - antennule; D - free postcephalothoracic somites and caudal rami (arrow showing leg 3), ventral; $\mathbf{E}$ - antenna; $\mathbf{F}$ - maxilla; $\mathbf{G}$ - maxillule; $\mathbf{H}$ - mandible; I - maxilliped.

Antennule (Fig. 2C) with distinctly but incompletely subdivided proximal segment bearing three long setae anteroventrally; distal segment bearing two aesthetascs and 11 setae, five of which branched terminally. Antenna (Fig. 2E) three-segmented; first segment (not illustrated) small, unarmed; second segment largest, with conspicuous inner process at proximal third; third segment smoothly curved inwardly, with minute inner seta proximally.

Mandible (Fig. 2H) consisting of four parts, bearing about 10 teeth on medial margin of distal blade. Maxillule (Fig. 2G) comprising weakly curved posterior process plus anterior papilla with three unequal setae. Maxilla (Fig. 2F) two-segmented; first segment (lacertus) unarmed; slender, second segment (brachium) carrying hyaline membrane on outer margin and two unequal elements (calamus and canna) terminally. Maxilliped (Fig. 2I) subchelate; proximal protopodal segment just longer than distal subchela; subchela comprising unarmed first endopodal segment and distal segment separated by distinct suture, carrying terminal claw and trifid setal element.

Legs 1 (Fig. 3A) and 2 (Fig. 3B) biramous with distinct, one-segmented rami; protopods divided into coxa and ba- sis; intercoxal sclerite present. Inner seta on basis of leg 1 absent. Seta and spine formula as follows:

\begin{tabular}{lcccc}
\hline & Coxa & Basis & Exopod & Endopod \\
\hline Leg 1 & $0-0$ & $1-0$ & III, I, 4 & 7 \\
Leg 2 & $0-0$ & $1-0$ & II, I, 4 & 6 \\
\hline
\end{tabular}

Leg 3 (arrowed in Fig. 2D) represented by short posterolateral process bearing one short spine and one long seta.

\section{First chalimus}

Fig. 4

Body 790-796 (792, $\mathrm{n}=17)$ long, attached to host by frontal filament (Fig. 4A). Cephalothorax about 2.3 times as long as free posterior somites combined. First free somite (= second pedigerous) wider than long; second free somite (= third pedigerous) narrower than first; third free somite longer than wide, bearing rudimentary leg 4; anal somite bearing small caudal rami with six unequal setae (Fig. 4B).

Antennule (Fig. 4C) two-segmented; proximal segment bearing seven setae; distal segment with 11 setae plus two aesthetascs. Antenna (Fig. 4D) modified from that of pre- 

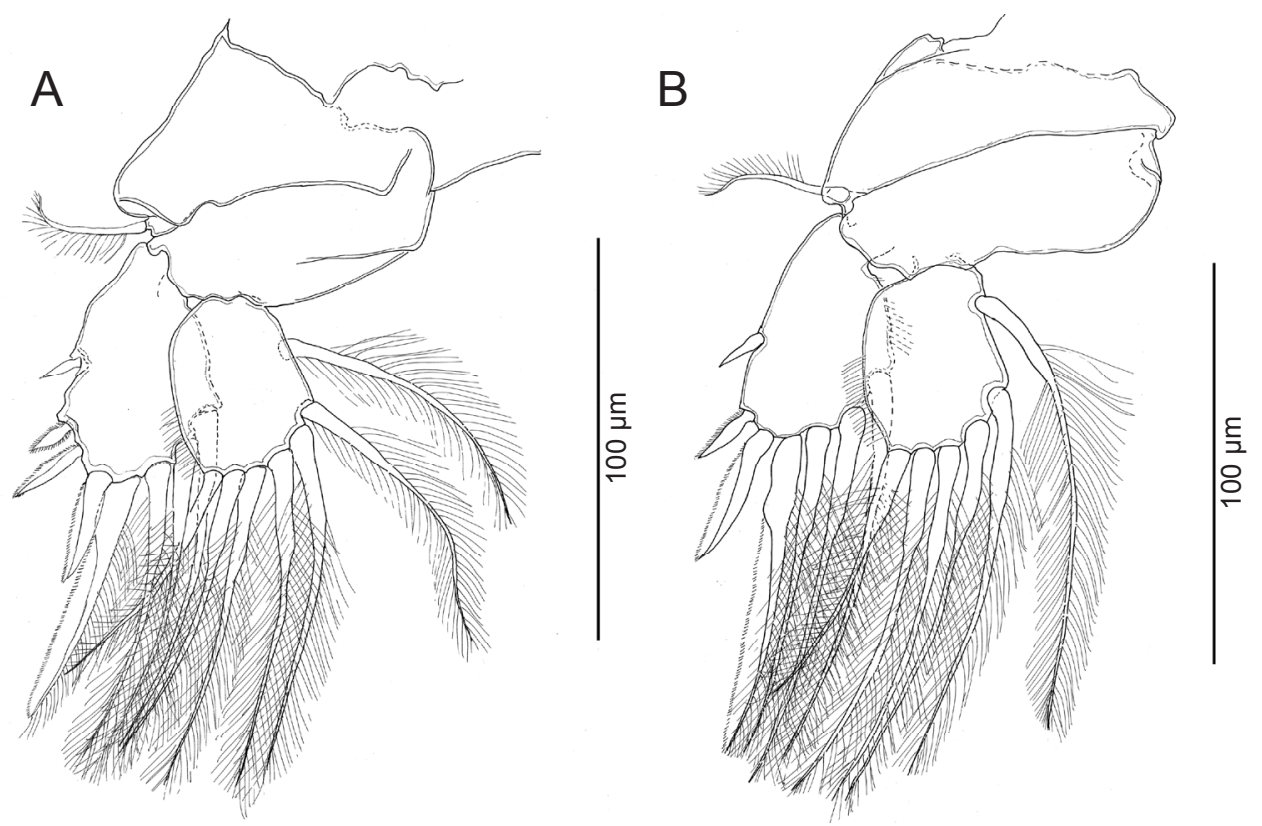

Fig. 3. Lepeophtheirus simplex Ho, Gómez et Fajer-Avila, 2001 from Sphoeroides annulatus. Copepodid: A - leg 1; B - leg 2.

ceding copepodid stage; consisting of broad basal segment and weakly sclerotised tip carrying short inner seta.

Mandible as in preceding copepodid stage. Maxillule (Fig. 4G) with posterior process broad and pointed, papilla with three unequal setae. Maxilla (Fig. 4F) two-segmented, first segment unarmed, second segment with short calamus and longer canna with minutely serrate membrane. Maxilliped (Fig. 4E) two-segmented, proximal segment robust; distal segment bearing curved claw and one subterminal inner seta.

Legs 1 (Fig. 4H), 2 (Fig. 4J) and 3 (Fig. 4I) biramous with one-segmented rami; leg 1 exopod elongate and endopod reduced from copepodid, comprising short segment with two naked setae apically; leg 2 with both rami more elongate than in preceding stage but both one-segmented; leg 3 with expanded sympod; size of rudimentary setae variable. Seta and spine formula as follows:

\begin{tabular}{lcccc}
\hline & Coxa & Basis & Exopod & Endopod \\
\hline Leg 1 & $0-0$ & $1-0$ & 8 & 2 \\
Leg 2 & $0-0$ & $1-0$ & 5 & 6 \\
Leg 3 & \multicolumn{2}{c}{$(0-0)$} & 6 & 4 \\
\hline
\end{tabular}

Leg 4 (arrowed in Fig. 4B) rudimentary, represented by two small setal elements.

\section{Second chalimus}

Fig. 5

Body length: $1.30-1.32 \mathrm{~mm}(1.31 \mathrm{~mm}, \mathrm{n}=36)$ long, with cephalothorax laterally expanded and incorporating both first and second pedigerous somites; cephalothorax about 2.5 times as long as free posterior somites combined; anterior margin with frontal filament (Fig. 5A). Third pedigerous somite free. Fourth pedigerous somite free, bearing anlagen of leg 4 ventrolaterally. Caudal ramus (Fig. 5B) broader than in preceding stage, with six unequal setae.
Antennule (Fig. 5C) proximal segment bearing 13 setae anteriorly; distal segment with 11 setae plus two aesthetascs. Antenna (Fig. 5F) obscurely segmented, with small curved claw terminally and two short setae.

Mandible, maxillule, maxilla and maxilliped unchanged.

Leg 1 (Fig. 5H) sympod indistinctly segmented; exopod with outer medial spine, four short distal and three short inner elements; endopod further reduced in size, vestigial. Leg 2 (Fig. 5E) sympod indistinctly segmented, medial seta pinnate; rami indistinctly separated from sympod; terminal margin of both rami with long pinnate setae. Leg 3 (Fig. 5G) broad sympod unsegmented, with outer protopodal seta lateral to base of exopod and stout seta (inner coxal seta) on posterior margin; exopod with seven setal elements; endopod with one seta on medial margin and four setae distally. Seta and spine formula as follows:

\begin{tabular}{lcccc}
\hline & Coxa & Basis & Exopod & Endopod \\
\hline Leg 1 & $0-0$ & $1-1$ & 8 & 1 \\
Leg 2 & $0-1$ & $1-0$ & 8 & 8 \\
Leg 3 & \multicolumn{2}{c}{$(1-1)$} & 7 & 5 \\
\hline
\end{tabular}

Leg 4 (Fig. 5D) uniramous; protopod indistinctly separate from developing exopod, with outer distal seta; exopod with four rudimentary elements. Leg 5 (arrowed in Fig. 5B) represented by two short setae.

\section{Pre-adult I, female}

Figs. 6, 7

Body 1.92-1.97 mm (1.95 mm, $\mathrm{n}=18)$ long, with cephalothorax incorporating third pedigerous somite; anterior margin with frontal filament (Fig. 6A). Typical Hshape suture line marks visible dorsally on cephalothoracic shield. Fourth pedigerous somite free, narrow, longer than wide. Genital complex just wider than long, bearing fifth 

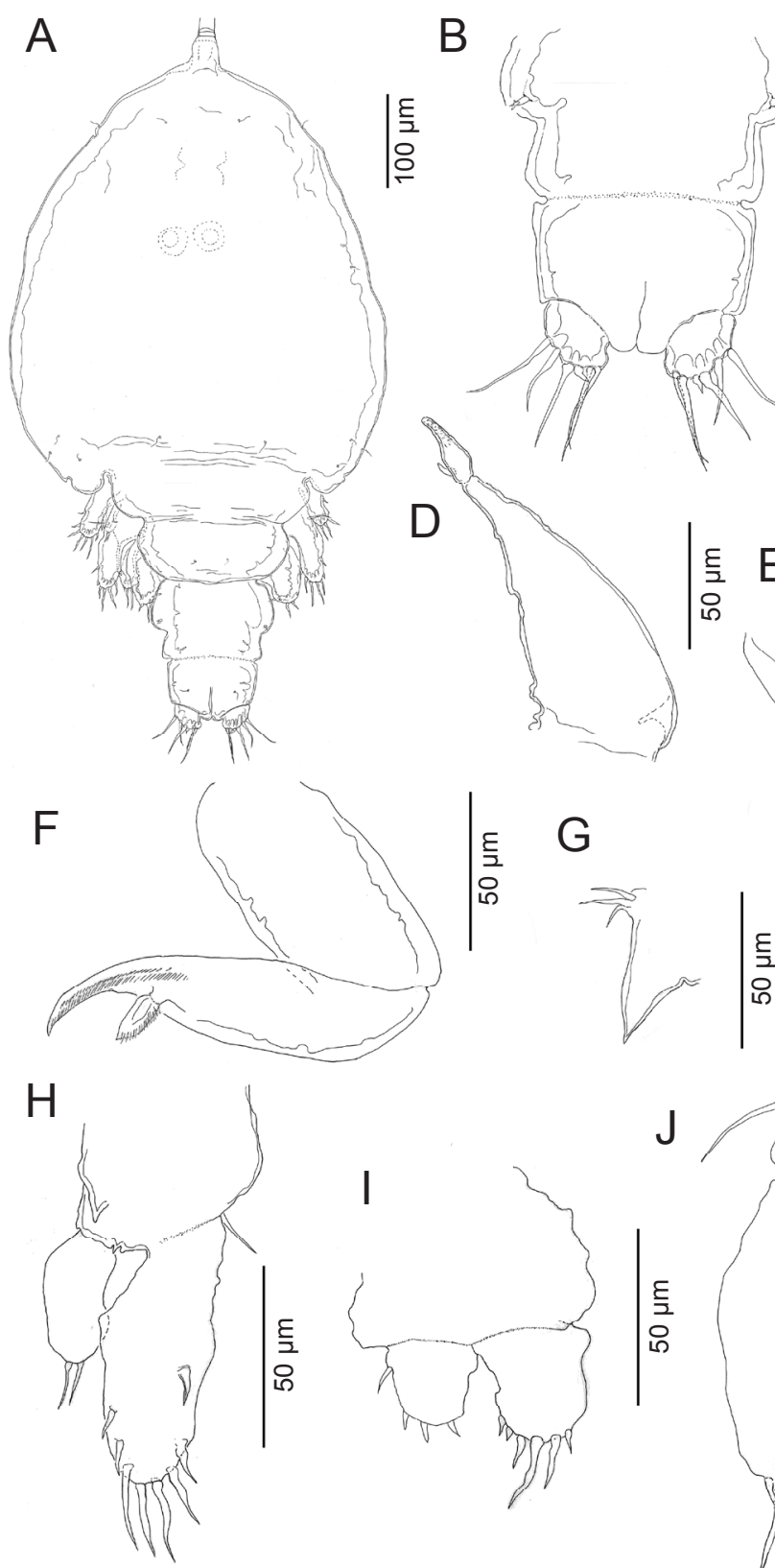

\section{C}

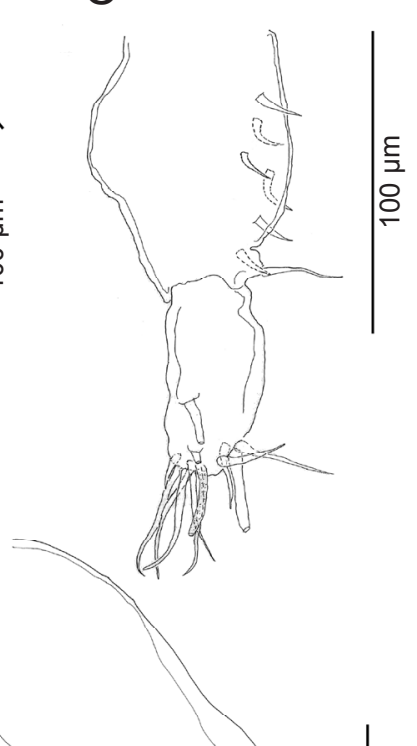

$\frac{\underline{\xi}}{2}$
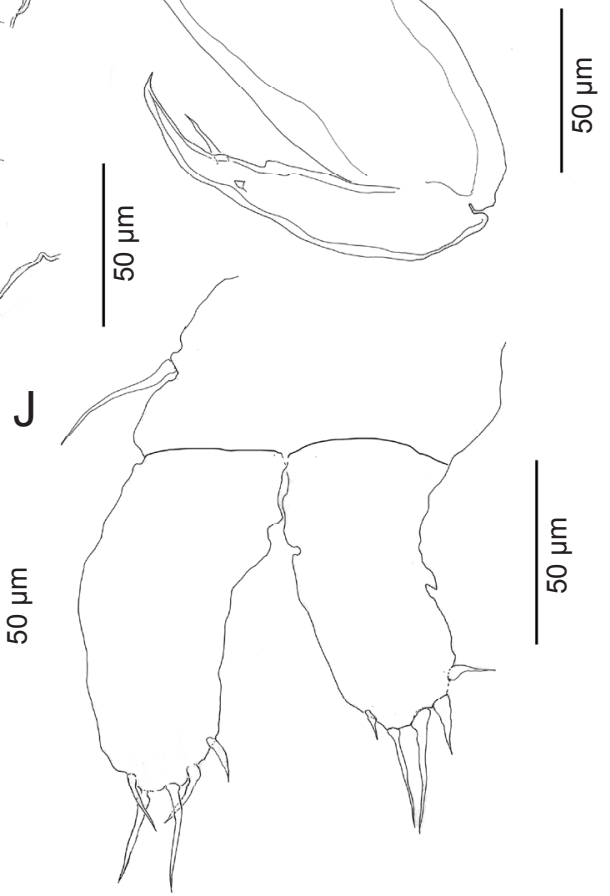

Fig. 4. Lepeophtheirus simplex Ho, Gómez et Fajer-Avila, 2001 from Sphoeroides annulatus. First chalimus: A - habitus, dorsal; $\mathbf{B}$ - third free somite (arrow showing rudimentary leg 4), anal somite, and caudal rami, ventral; $\mathbf{C}$ - antennule; D - antenna; E - maxilliped; F - maxilla; $\mathbf{G}$ - maxillule; $\mathbf{H}$ - leg $1 ; \mathbf{I}-\operatorname{leg} 3 ; \mathbf{J}-\operatorname{leg} 2$.

legs. Free abdomen one-segmented, rectangular; caudal ramus (Fig. 6B) with six plumose setae.

Antennule (Fig. 6C) proximal segment with array of 20 plumose setae, 18 on anteroventral surface and two on dorsal surface; distal segment with 12 setae plus two aesthetascs.

Antenna (Fig. 6D) three-segmented, proximal segment broad, with short, stout inner process; middle segment with rudiment of dorsal adhesion pad discernible; distal segment sharply pointed and strongly bent claw bearing one seta in proximal region and another in middle region.

Mandible unchanged. Maxillule (Fig. 6H) of typical adult form, comprising posteriorly-directed process plus anterior papilla with three setae. Maxilla with distal segment (Fig. 6F) more slender than in preceding stage. Max- illiped (Fig. 6G) three-segmented, protopodal segment robust; distal endopodal segment of subchela bearing curved claw and short inner seta. Sternal furca (Fig. 6I) present.

Leg 1 (Fig. 7B) of adult form; sympod with one outer seta and another on inner margin. Exopod distinctly twosegmented, proximal segment elongate, about twice as long as distal segment, with outer distal spine and row of setules along medial margin; distal segment with three pinnate setae on medial margin, one seta on distal inner corner and three stout spines on terminal margin. Endopod vestigial, bearing one tiny, subterminal inner seta.

Leg 2 (Fig. 7A) biramous. Intercoxal plate with marginal membrane along free posterior margin. Coxa short, with pinnate seta. Basis with outer distal seta; inner margin 

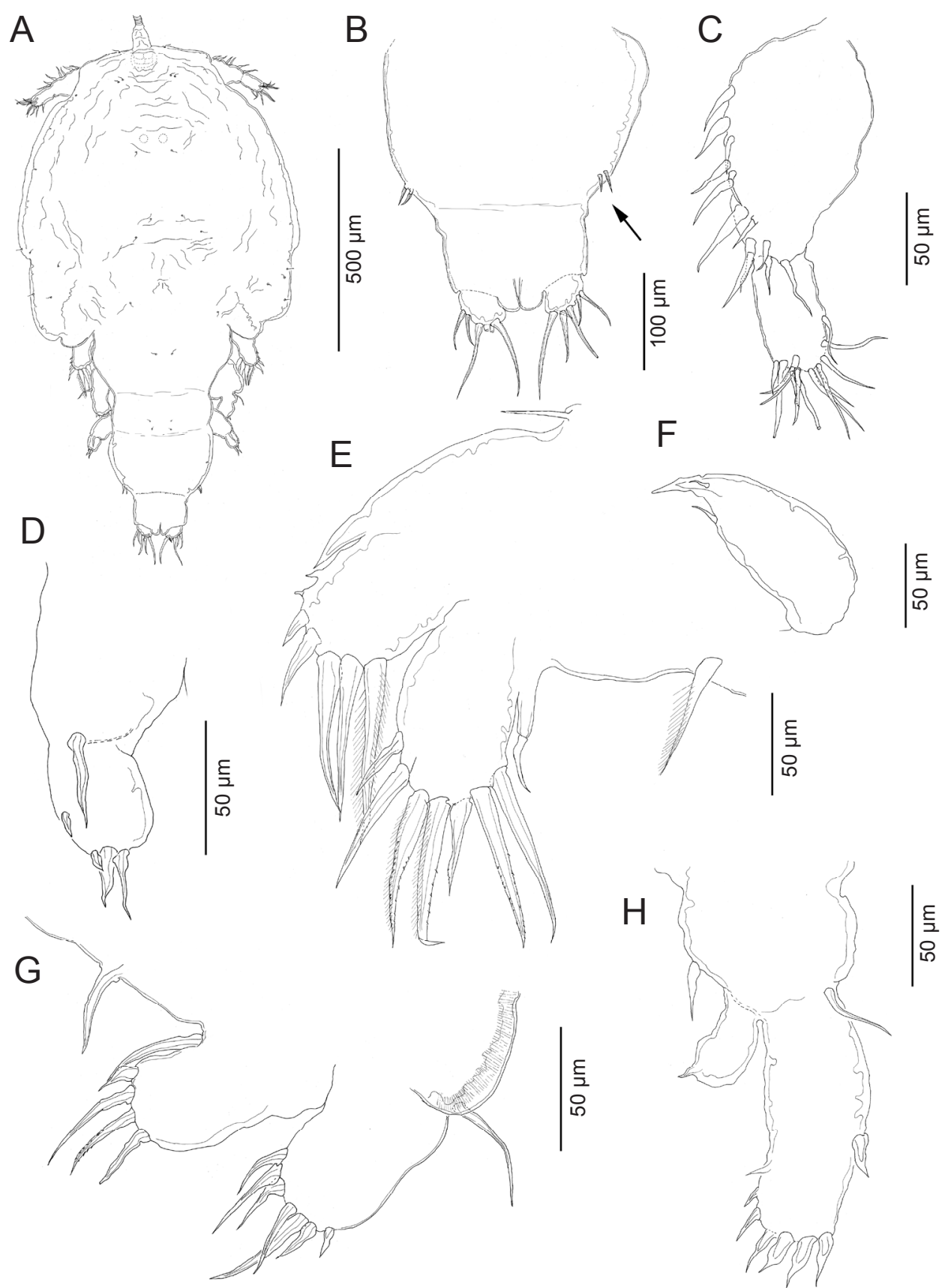

Fig. 5. Lepeophtheirus simplex Ho, Gómez et Fajer-Avila, 2001 from Sphoeroides annulatus. Second chalimus: A - habitus, dorsal; $\mathbf{B}$ - posterior part of body (arrow showing leg 5), ventral; $\mathbf{C}$ - antennule; D - leg 4; E - leg 2; F - antenna; $\mathbf{G}-\operatorname{leg} 3 ; \mathbf{H}-\operatorname{leg} 1$.

with marginal membrane and single sensilla. Exopod twosegmented; proximal segment with outer spine and inner seta; distal segment with two short spines (outermost distal spine with membrane) and five pinnate setae. Endopod two-segmented, proximal segment shorter than distal one, with long pinnate seta on medial margin; distal segment with eight pinnate setae.

Leg 3 (Fig. 7C) forming flattened plate, as in adult. Protopodal part flattened, sympod bearing inner pinnate seta and outer plumose seta near base of exopod; with extensive membrane posteriorly, medial to endopod, and laterally, anterior to exopod. Exopod two-segmented, proximal segment bearing pinnate seta medially and one spine; distal segment with three short spines and six plumose setae.
Endopod two-segmented; proximal segment with pinnate seta medially; distal segment with five long pinnate setae medially. Setal formula as follows:

\begin{tabular}{lcccc}
\hline & Coxa & Basis & Exopod & Endopod \\
\hline Leg 1 & $0-0$ & $1-1$ & I-0; III, 1, 3 & (vestigial) \\
Leg 2 & $0-1$ & $1-0$ & I-1; II, I, 5 & $0-1 ; 8$ \\
Leg 3 & \multicolumn{2}{c}{$(1-1)$} & I-1; III, 6 & $0-1 ; 5$ \\
\hline
\end{tabular}

Leg 4 (Fig. 7D) uniramous, two-segmented; protopodal segment with single pinnate seta at outer distal corner; exopod with two spiniform lateral elements and three unequal distal elements with fine spinules along margins. Leg 

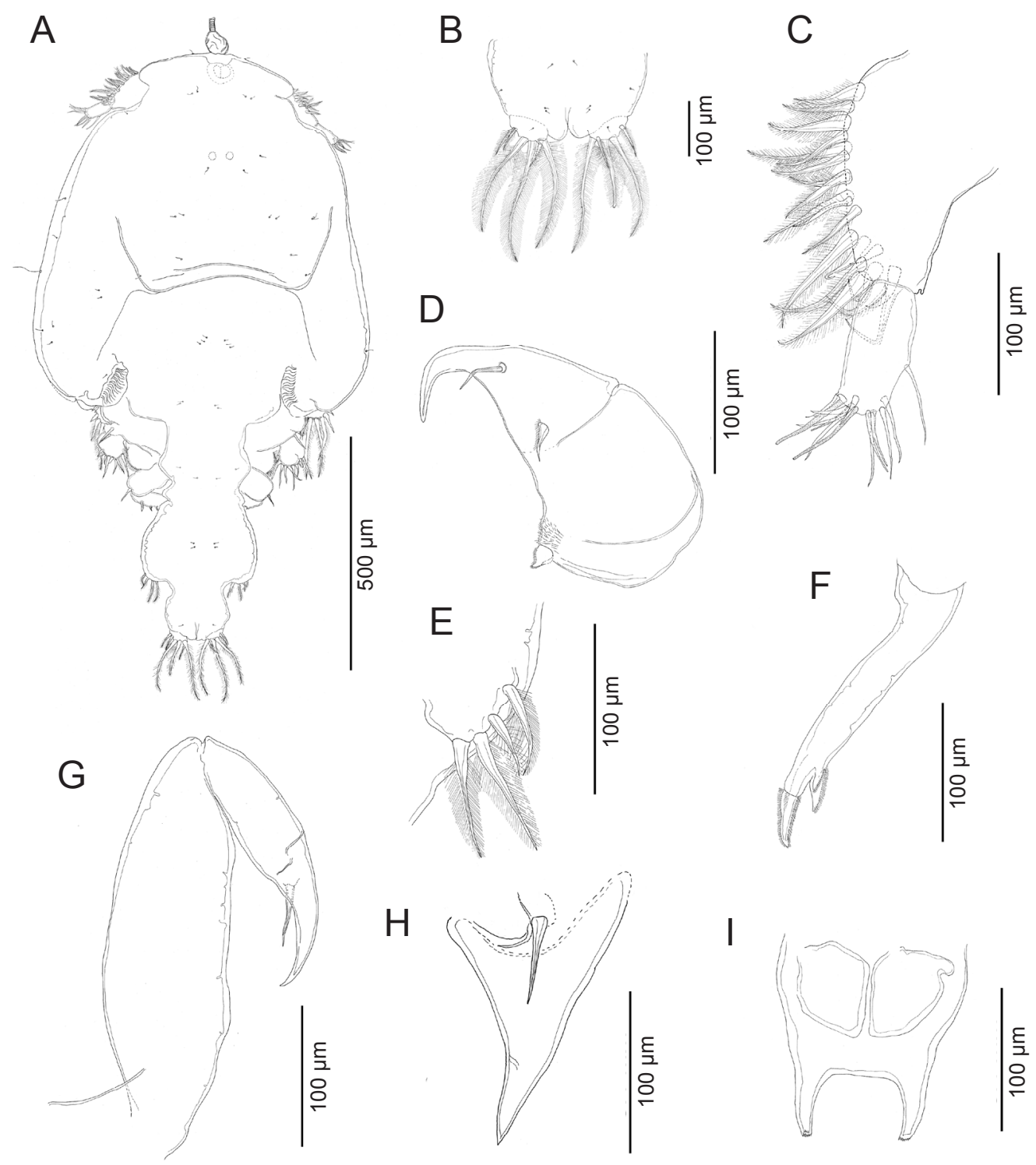

Fig. 6. Lepeophtheirus simplex Ho, Gómez et Fajer-Avila, 2001 from Sphoeroides annulatus. Pre-adult I, female: A - habitus, dorsal; $\mathbf{B}$ - anal somite and caudal rami, ventral; $\mathbf{C}$ - antennule; D - antenna; $\mathbf{E}$ - leg 5; F - last segment of maxilla; $\mathbf{G}$ - maxilliped; $\mathbf{H}$ - maxillule; I - sternal furca.

5 (Fig. 6E) represented by lobe at distal corner of genital complex, with two short and two long pinnate setae.

Pre-adult I, male: unknown.

\section{Pre-adult II, female}

Figs. $8,9 \mathrm{~B}, \mathrm{D}, \mathrm{E}$

Body $2.42-2.44 \mathrm{~mm}(2.42 \mathrm{~mm}, \mathrm{n}=17)$ long. Body (Fig. $8 \mathrm{~A}$ ) with cephalothorax wider than in preceding stage and with well-developed frontal plates. Cephalothorax about two times as long as post-cephalothoracic somites and caudal rami combined. Frontal plates, lateral margins of cephalothorax and posterior sinuses with marginal membrane. Genital complex wider than long, laterally more swollen than in preceding stage. Free abdomen and caudal ramus (Fig. 8B) unchanged.

Antennule (Fig. 8D) two-segmented; proximal segment with 25 plumose setae along anteroventral margin and two setae located dorsally; distal segment with medial seta on posterior margin and 11 setae plus two aesthetascs distally.
Antenna unchanged (Fig. 8E), with postantennary process (Fig. 8C) represented by small oval process with three papillae bearing setules. Mandible, maxillule, maxilla, maxilliped, and sternal furca as in preceding stage.

Leg 1 (Fig. 8F) as in preceding stage, except for middle two of four terminal elements on distal segment of exopod with accessory process. Leg 2 (Fig. 8G) as in preceding stage, except for distal segment of exopod with two short spines, one outer distal spine with membrane and six pinnate setae. Leg 3 (Fig. 9B) as in preceding stage, except for distal segment of endopod with six long pinnate setae medially. Setal formula as follows:

\begin{tabular}{lcccc}
\hline & Coxa & Basis & Exopod & Endopod \\
\hline Leg 1 & $0-0$ & $1-1$ & I-0; III, 1, 3 & (vestigial) \\
Leg 2 & $0-1$ & $1-0$ & I-1; II, I, 6 & $0-1 ; 8$ \\
Leg 3 & \multicolumn{2}{c}{$(1-1)$} & I-1; III, 6 & $0-1 ; 6$
\end{tabular}



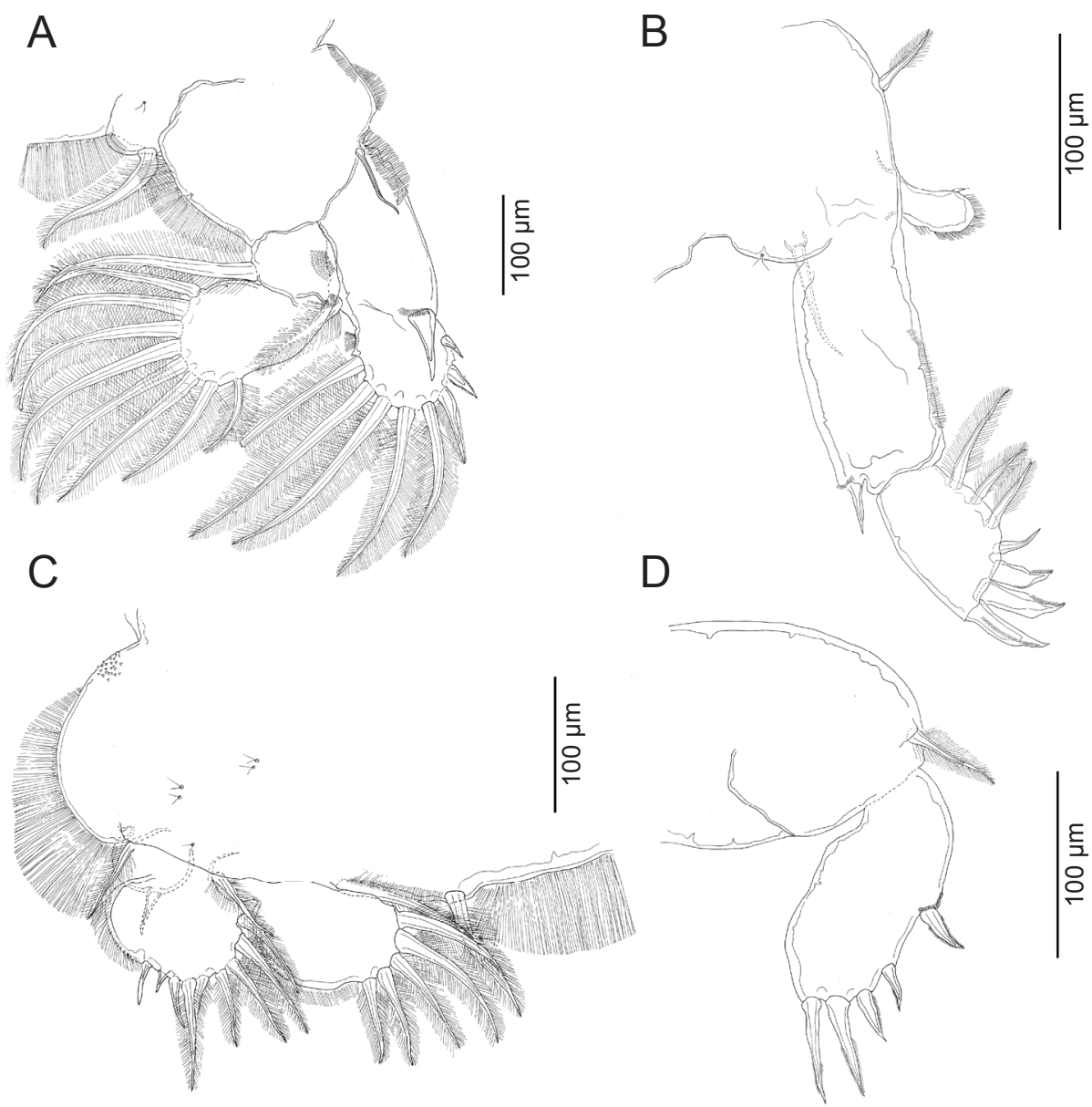

Fig. 7. Lepeophtheirus simplex Ho, Gómez et Fajer-Avila, 2001 from Sphoeroides annulatus. Pre-adult I, female: A - leg 2; B - leg 1; C-leg $3 ; \mathbf{D}-\operatorname{leg} 4$.

Leg 4 (Fig. 9D) as in preceding stage, except for exopod indistinctly two-segmented and spines with pecten at base. Leg 5 (Fig. 9E) represented by pinnate seta and small process tipped with three pinnate setae.

\section{Pre-adult II, male}

Fig. 9A,C

Body length: $1.94-1.97 \mathrm{~mm}(1.95 \mathrm{~mm}, \mathrm{n}=17)$ long. General appearance (Fig. 9A) as in female, but differing in shape of genital complex and abdomen. Proximal segment of antenna without inner process. Genital complex narrower than that of female. Free abdominal somite shorter than in female. Leg 5 as in female, but situated on lateral margin of genital complex just posterior to widest point. Leg 6 (Fig. 9C) represented by three plumose setae on distal corner of genital complex.

\section{Time of the development of Lepeophtheirus simplex}

The mean development time from hatching of the nauplii to the infectious copepodid was $32 \mathrm{~h}$ (1.3 days). Development from the copepodid through the chalimus phase of L. simplex was analysed graphically using the percentages of the different stages commencing at day 1 with an original inoculum of copepodids (Fig. 10). The copepodid stage was only found on days 1 and 2 . The main proportion $(100 \%)$ of chalimus I appeared on day 3 , even though this stage was first observed on day 2 and could be found until day 6 at a low level (2\%). Chalimus II mostly appeared on days 4 and 5 (63 and 55\%, respectively), but it was observed until day $10(3 \%)$. Pre-adult I occurred from day 5 until day 10; however, the highest proportion (45\%) was found on day 6 . Pre-adult II, both female and male, first appeared on day 5, but the highest proportion $(92 \%$, pooling both sexes) occurred on day 7. Adult male first appeared on day 7 at low level (5\%), whereas adult female first appeared on day 8 . Ovigerous females appeared with a proportion of $35 \%$ on day 11 , when all copepods observed were adults.

\section{Fecundity of Lepeophtheirus simplex}

Ovigerous females of L. simplex were collected in April, May, August, October and December 2007, and March, April, May, June, July and September 2013, with water temperature ranging from $21.1^{\circ} \mathrm{C}$ (December) to $31.8^{\circ} \mathrm{C}$ (August) (Table 1). Data for the remaining months of the study period were not obtained because sampling of fish was not possible or ovigerous females (OF) were not found on fish. In total 169 OF were measured, with body length ranging between 2.2 and $4.1 \mathrm{~mm}$, egg string length between 1 and $2.5 \mathrm{~mm}$, fecundity between 12 and 36 eggs per string, and average egg length between 70 and $300 \mu \mathrm{m}$ (Table 1). Fecundity showed a strong negative correlation with the average egg length $(r=-0.888$, 


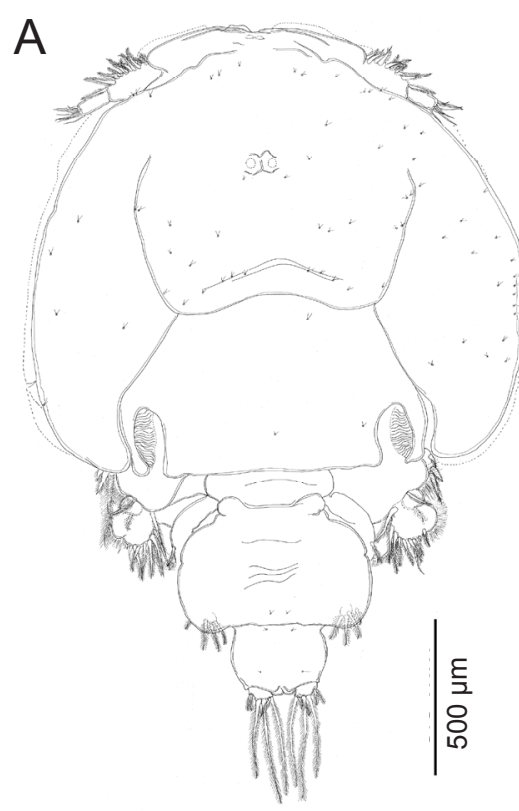

B
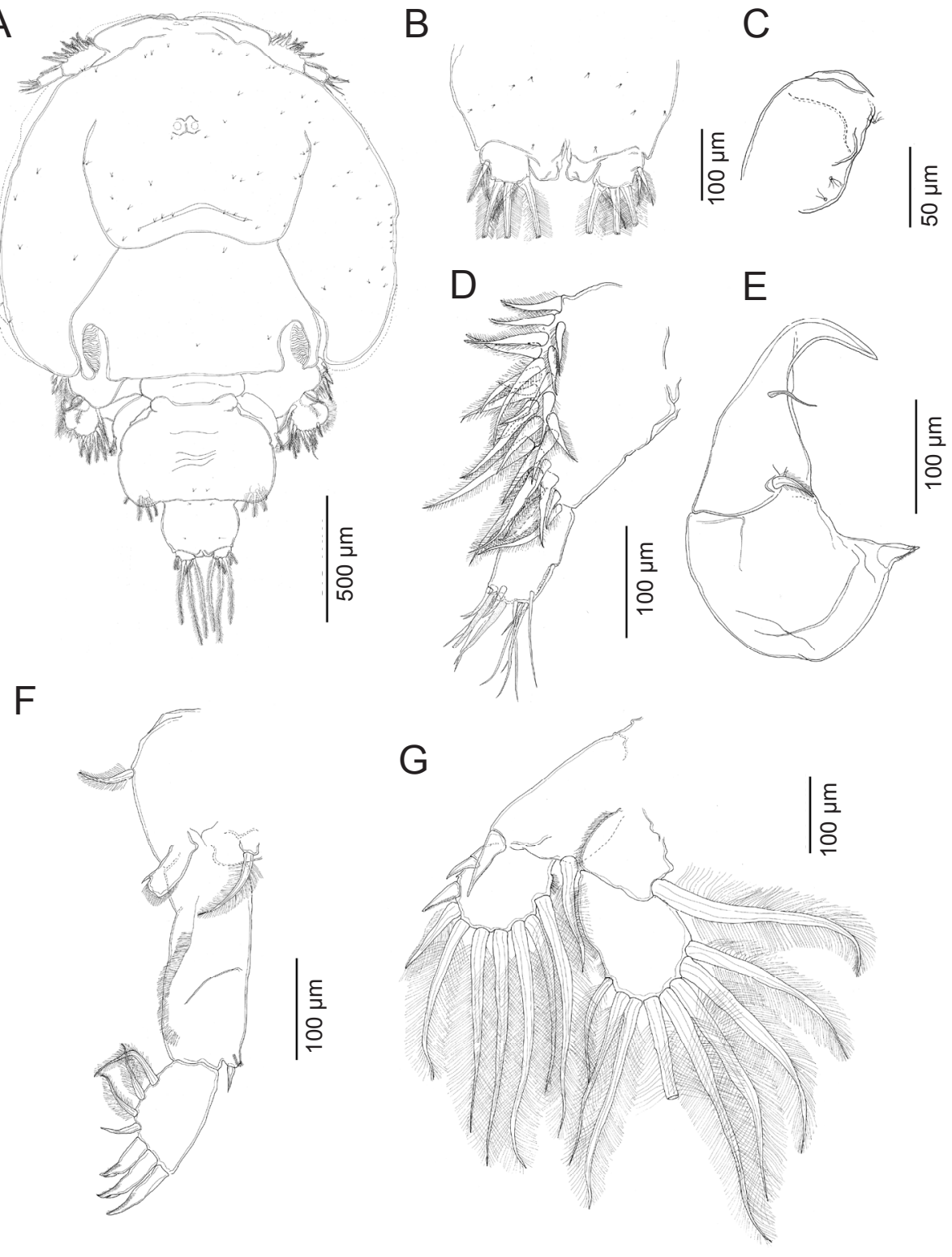

Fig. 8. Lepeophtheirus simplex Ho, Gómez et Fajer-Avila, 2001 from Sphoeroides annulatus. Pre-adult II, female: A - habitus, dorsal; $\mathbf{B}$ - anal somite and caudal rami, ventral; C - postantennary process; D - antennule; E - antenna; F - leg 1; G - leg 2 endopod and exopod.

$\mathrm{p}<0.001$ ) (Fig. 11) and a positive correlation with the egg string length $(r=0.682, p<0.001)$. Neither OF body length nor water temperature were significantly correlated with the fecundity $(r=0.096$ and -0.041 , respectively, $p>0.05)$. Water temperature was only significantly and negatively associated with $\mathrm{OF}$ body length, but with a low coefficient value $(\mathrm{r}=-0.268, \mathrm{p}<0.001)$.

Sampling months with fewer than ten data (May, August and December 2007, and April 2013) were not included in the Kruskal-Wallis test, which indicated significant differences in OF body length among sampling months $(\mathrm{H}=21.555, \mathrm{p}<0.01)$, with larger $\mathrm{OF}$ during March than during both June and July 2013 ( $\mathrm{p}<0.05$ ) (Table 1). Neither egg string length, nor average egg length, nor fecundity varied significantly among sampling months $(\mathrm{p}>0.05)$.

\section{DISCUSSION}

The life cycle of Lepeophtheirus simplex comprises two nauplius stages, an infective (copepodid) stage, two chalimus stages and two pre-adult stages preceding the adult. This life cycle fits with those described by Ohtsuka et al. (2009), Hamre et al. (2013) and Venmathi Maran et al. (2013), who observed that Lepeophtheirus species retain six post-naupliar stages typically observed in members of the subclass Copepoda. There is no doubt that two nauplius are common in all caligids for which the life cycle is known. However, until recently, it was recognised that species of Lepeophtheirus had eight post-naupliar stages (one copepodid, four chalimus, two pre-adults and the adult) (Lewis 1963, Boxshall 1974, Johnson and Albright 1991a).

This addition of stages drew attention since copepods are characterised by six post-naupliar stages and parasitic 


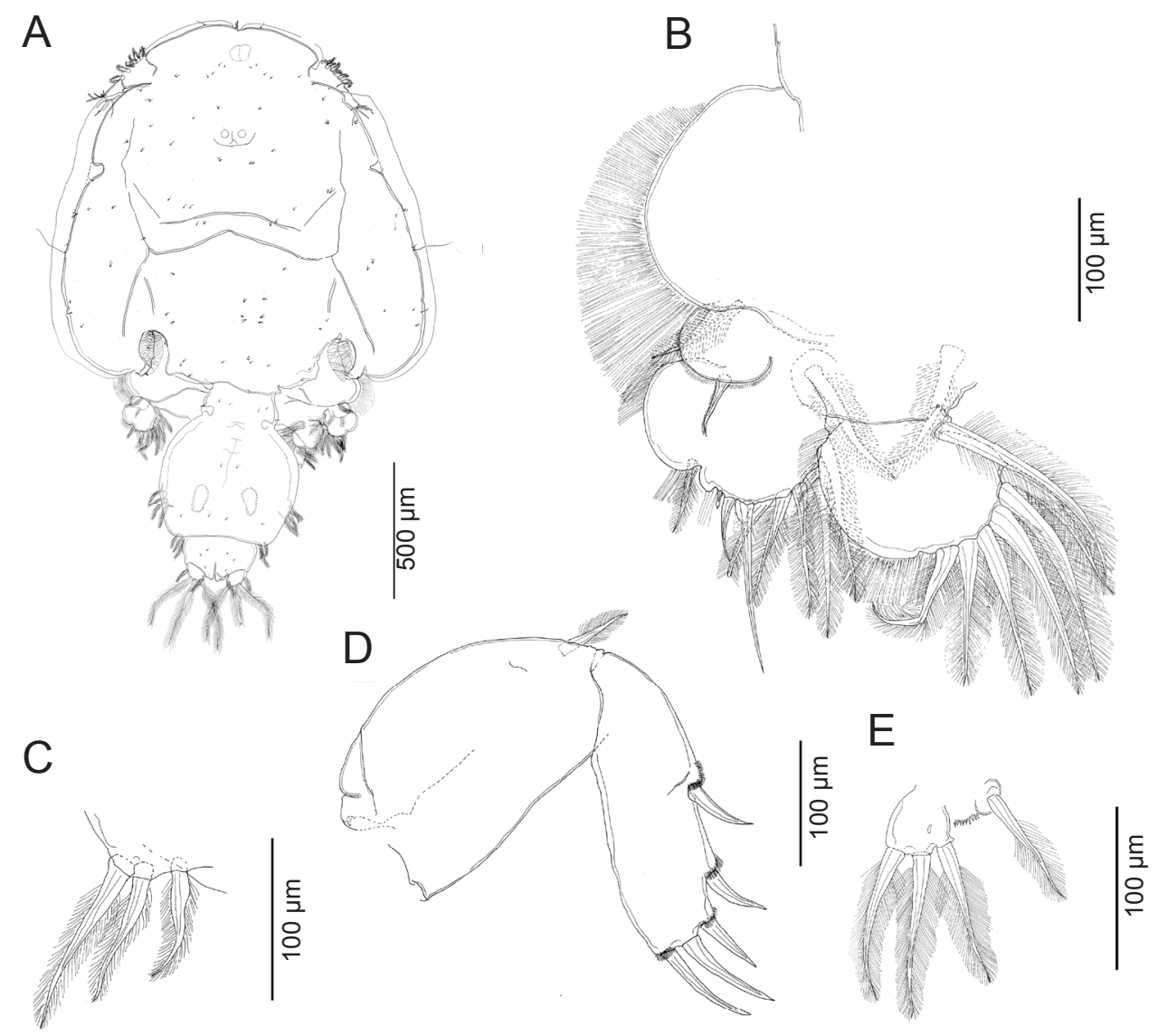

Fig. 9. Lepeophtheirus simplex Ho, Gómez et Fajer-Avila, 2001 from Sphoeroides annulatus. Pre-adult II, A - habitus, dorsal, male; B - leg 3, female; C-leg 6, male; D - leg 4, female; E - leg 5, female.

copepods trend to exhibit abbreviated life cycles (Boxshall 2005, Ohtsuka et al. 2009). Thus, based on the number of setae on the proximal segment of the antennule, Ohtsuka et al. (2009) suggested that $L$. salmonis and L. pectoralis have only two chalimus stages. However, these authors indicated that an examination of the number of true instars (stages separated by molts) would be necessary.

Later, using that number of setae as a stage marker in L. elegans, Venmathi Maran et al. (2013) provided more evidence about the life cycle of caligids concluding that they have a common life cycle pattern that includes two naupliar, one copepodid and four chalimus stages preceding the adult in Caligus, but with four chalimus stages represented by two chalimus and two pre-adult stages in Lepeophtheirus. These findings were strongly reinforced by Hamre et al. (2013), who observed molting of chalimus stages in incubators and analysed their morphometry, concluding that there are only two chalimus instars in the life cycle of L. salmonis and possibly in the other Lepeophtheirus species as well.

In the present study, the number of post-naupliar stages of $L$. simplex was assessed using the number of setae on the proximal segment of the antennule, with 3 setae in the copepodid, 7 in chalimus I, 13 in chalimus II, 20 in preadult I and 27 in pre-adult II. The adult of $L$. simplex also has 27 setae on the proximal segment of the antennule (Ho et al. 2001). However, according to Venmathi Maran et al. (2013), the change from two to three segments in both rami of leg 2 is evidence of a molt between pre-adult II and adult. Also, molting between pre-adult II and adult observed in L. pectoralis by Anstensrud (1990) could indicate that these are really two different stages in Lepeophtheirus species.

The number of setae $(3,7,13,20,27$ and 27 , respectively) on the proximal segment of the antennule at each post-naupliar stage of $L$. simplex is the same as observed in L. elegans - Venmathi Maran et al. (2013). According to Ohtsuka et al. (2009) these numbers may also be found in L. salmonis and L. pectoralis, except that in the latter species there are 14 instead of 13 setae in chalimus II. Therefore, our results support the hypothesis that all caligids have the same life cycle; nonetheless, the developmental stages of only few caligids are known so far.

Unfortunately, we were unable to observe the pre-adult I male of $L$. simplex. A possible explanation would be that development time during this stage was relatively shorter in males than in females and thus pre-adult I males were not available at the time of the sampling. In fact, it has been observed in other species of sea lice that males develop faster than females. For instance, the generation time for C. elongatus and L. salmonis at $10^{\circ} \mathrm{C}$ is approximately 40 days for males and 50 days for females (see Costello 2006 and references therein). Likewise, C. rogercresseyi needs 193 and 208 degree-days (effective temperature multiplied by the number of days required to complete development) to reach adult male and female, respectively (González and Carvajal 2003). 
Table 1. Body dimension and reproductive effort of females of Lepeophtheirus simplex on Sphoeroides annulatus.

\begin{tabular}{lccccccccccc}
\hline & \multicolumn{9}{c}{2007} & \multicolumn{1}{c}{2013} \\
\cline { 2 - 12 } & April & May & August & October & December & March & April & May & June & July & September \\
\hline OF & 16 & 4 & 7 & 15 & 7 & 11 & 5 & 31 & 13 & 34 & 26 \\
BL & $3.0-4.1$ & $3.2-3.7$ & $3.2-4.1$ & $2.8-3.7$ & $2.4-3.6$ & $3.2-4.1$ & $3.4-3.8$ & $2.2-4.0$ & $2.8-3.6$ & $2.2-3.8$ & $3.0-3.7$ \\
& $(3.4 \pm 0.3)$ & $(3.5 \pm 0.2)$ & $(3.4 \pm 0.3)$ & $(3.2 \pm 0.3)$ & $(3.1 \pm 0.4)$ & $(3.6 \pm 0.3)$ & $(3.5 \pm 0.2)$ & $(3.4 \pm 0.3)$ & $(3.2 \pm 0.2)$ & $(3.2 \pm 0.3)$ & $(3.3 \pm 0.2)$ \\
SL & $1.0-2.3$ & $1.6-1.8$ & $1.3-2.1$ & $1.3-2$ & $1.4-2.4$ & $1.1-2.5$ & $1.4-2.3$ & $1.2-2.4$ & $1-1.9$ & $1.3-2.1$ & $1-2.2$ \\
& $(1.7 \pm 0.3)$ & $(1.7 \pm 0.1)$ & $(1.7 \pm 0.3)$ & $(1.7 \pm 0.2)$ & $(1.6 \pm 0.4)$ & $(1.8 \pm 0.5)$ & $(1.9 \pm 0.3)$ & $(1.7 \pm 0.3)$ & $(1.6 \pm 0.2)$ & $(1.6 \pm 0.2)$ & $(1.5 \pm 0.3)$ \\
E/S & $12-28$ & $17-28$ & $17-27$ & $17-30$ & $17-30$ & $16-36$ & $17-32$ & $16-32$ & $12-25$ & $17-31$ & $15-32$ \\
& $(22 \pm 4.7)$ & $(23 \pm 4.8)$ & $(22 \pm 3.8)$ & $(23 \pm 4.6)$ & $(23 \pm 6.5)$ & $(23 \pm 6.5)$ & $(28 \pm 5.9)$ & $(24 \pm 4.6)$ & $(22 \pm 3.7)$ & $(23 \pm 4.6)$ & $(22 \pm 5.5)$ \\
EL & $110-300$ & $110-210$ & $130-190$ & $110-220$ & $110-190$ & $100-220$ & $110-190$ & $110-200$ & $120-300$ & $70-210$ & $100-230$ \\
WT & $(170 \pm 50)$ & $(160 \pm 50)$ & $(150 \pm 20)$ & $(150 \pm 30)$ & $(140 \pm 30)$ & $(160 \pm 40)$ & $(130 \pm 30)$ & $(140 \pm 30)$ & $(150 \pm 50)$ & $(140 \pm 30)$ & $(160 \pm 40)$ \\
\hline
\end{tabular}

Range (mean \pm standard deviation); OF - No. of ovigerous females; BL - body length (mm), SL - string length (mm); E/S - No. of eggs/string; EL - average egg length (in $\mu \mathrm{m})$; WT - water temperature $\left({ }^{\circ} \mathrm{C}\right)$.

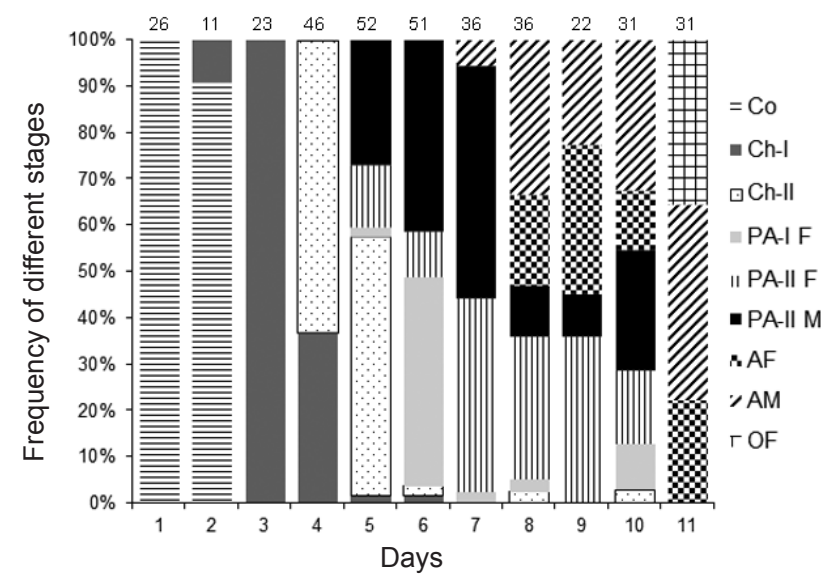

Fig. 10. Temporal change in composition of developmental stages of Lepeophtheirus simplex after infection with Sphoeroides annulatus copepodids. Numbers above each column represent the total number of individuals examined. Abbreviations: Co - copepodid, Ch-I - chalimus I, Ch-II - chalimus II, PA-I F - pre-adult I female, PA-II F - pre-adult II female, PA-II M - pre-adult II male, $\mathrm{AF}$ - adult female, $\mathrm{AM}$ - adult male, $\mathrm{OF}$ - ovigerous female.

Based on the development time for copepodid of 1.3 days and that adults appeared 8 days post infection, the generation time from egg extrusion to adult for $L$. simplex was approximately ten days at $22^{\circ} \mathrm{C}$. To our knowledge there are no similar studies for other species of Lepeophtheirus from tropical or subtropical waters. However, similar development times have been observed in C. epidemicus, C. fugu, and $C$. pageti. The chalimus phase of C. epidemicus lasted eight days and it took 17 days to develop from hatching to $\mathrm{OF}$ at $24.5^{\circ} \mathrm{C}$ (Lin and Ho 1993). The average duration from copepodid to adult for $C$. fug $u$ was about 16 days at $18.6-20.2^{\circ} \mathrm{C}$, although the shortest duration was nine days (Ohtsuka et al. 2009). In C. pageti the developmental cycle was completed from ten to 11 days at $24-26^{\circ} \mathrm{C}$ (see discussion in Lin and Ho 1993).

In contrast, longer generation times have been observed in L. salmonis and other species of sea lice from cold or temperate waters. For instance, Johnson and Albright (1991b) observed that the development of $L$. salmonis took nine days at $5{ }^{\circ} \mathrm{C}$, three days at $10^{\circ} \mathrm{C}$ and two days at $15^{\circ} \mathrm{C}$ from the first nauplius to the copepodid, whereas the devel-

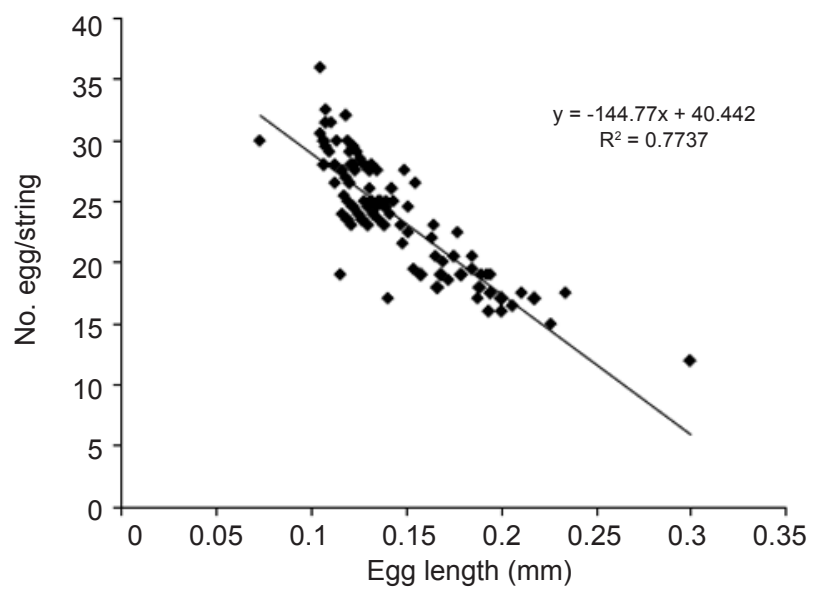

Fig. 11. Relationship between number of eggs per string and average egg length in females of Lepeophtheirus simplex.

opment from egg to adult male and female at $10^{\circ} \mathrm{C}$ took 40 and 52 days. González and Carvajal (2003) reported a generation time of 45 days at $10^{\circ} \mathrm{C}, 32$ days at $12.8^{\circ} \mathrm{C}$, and 26 days at $15^{\circ} \mathrm{C}$ for $C$. rogercresseyi. These findings suggest that changes in temperature not only affects the generation time at the intraspecific level, but also at interspecific level, with species of sea lice from warm waters (i.e. low latitudes) having shorter life cycles than those species from temperate or cold waters (i.e. high latitudes).

In the present study, the egg numbers per string as well as the egg string length of $L$. simplex remained unchanged year-round. It was not expected since previous studies pointed out that sea lice live longer and grow larger at colder temperatures, and larger females produce more eggs (Pike and Wadsworth 1999, Costello 2006). Our results contrast with seasonal changes in reproductive output reported for L. salmonis, with egg numbers and egg strings significantly higher in winter than in summer (Tully 1989, Ritchie et al. 1993). Likewise, Bravo et al. (2009) reported females of $C$. rogercresseyi with egg strings longer and higher number of eggs per string in winter than in summer.

This is possibly because C. rogercresseyi and $L$. salmonis are found at high latitudes where there is a more marked seasonality compared with the lower latitudes where L. simplex was collected. However, González et al. (2012) observed that the variations in fecundity of C. rog- 
ercresseyi are explained by variations in body length of OF rather than month of the year, because OF body length varies across months of the year. Furthermore, in both $C$. rogercresseyi and L. salmonis a positive correlation has been noted between body length and egg number (Tully and Whelan 1993, González et al. 2012, Bravo et al. 2013). Here, such correlation was not observed for L. simplex, although in March (a relatively cold month) females were significantly larger and their fecundity did not change with respect to the other months of the year.

Thus, probably, the natural fluctuation in temperature does not affect the fecundity of $L$. simplex. It should be noted that Morales-Serna et al. (2011) reported high infection levels of L. simplex on S. annulatus during the warmest season of the year. According to the present study, this could be due to a reduction in generation time rather than to an increase in fecundity of L. simplex. In order to test this hypothesis, future analysis comparing the generation time of L. simplex at different temperature regimes should be performed.

The number of eggs (12-36 eggs per string) produced by $L$. simplex is low if compared with 100-500 eggs per string produced by L. salmonis (Pike and Wadsworth 1999). Within the Caligidae, fecundity may be very variable among species. Ohtsuka et al. (2009) pointed out that there is a poor knowledge about this subject, but the number of eggs per string in Taiwanese and Japanese caligids can vary from 4 to 253 . In the present study, based on correlation analysis, it was detected that there is a tradeoff between quantity and quality of eggs in L. simplex populations: some females produce longer egg strings with a greater number of smaller eggs and the others produce shorter egg string with a lower number of greater eggs.

The same happens in L. salmonis, although Ritchie et al. (1993) observed that the greater numbers of small eggs were produced by winter generations, suggesting that temperature may be interacting with endogenous factors to cause alterations in the expenditure of energy for reproductive output. However, as we did not observe seasonal changes, it is possible that the variability in fecundity within the L. simplex population is an infection strategy under selection given the unpredictable nature of parasite transmission (Poulin 2007).

In order to understand the infection dynamics of sea lice on marine fishes from Mexican Pacific, more information concerning its biology should be provided in the future. For instance, if the generation time is effectively reduced at higher temperatures, then an increase in the abundance of sea lice could be expected due to the global warming, which could be a major issue for the development of marine fish farming in Mexico.

Acknowledgements. We thank Dr. José Salgado Barragán (ICML-UNAM), Néstor Arenas Díaz and Jesús Zatarain Delgado for their help in the field and laboratory. AIRS thanks the National Council of Science and Technology (CONACyT) for a scholarship that facilitated the completion of her MSc degree. FNMS was supported by a grant from the CONACyT. The comments from two anonymous reviewers greatly improved an earlier version of this contribution.

\section{REFERENCES}

Anstensrud M. 1990: Moulting and mating in Lepeophtheirus pectoralis (Copepoda: Caligidae). J. Mar. Biol. Assoc. U.K. 70: 269-281.

Boxshall G.A. 1974: The developmental stages of Lepeophtheirus pectoralis (Müller, 1776) (Copepoda: Caligidae). J. Nat. Hist. 8: 681-700.

Boxshall G.A. 1990: The skeletomusculature of siphonostomatoid copepods, with an analysis of adaptative radiation in structure of the oral cone. Phil. Trans. Roy. Soc. B. 328: 167-212.

Boxshall G.A. 2005: Copepoda (copepods). In: K. Rohde (Ed.), Marine Parasitology. CSIRO Publishing, Melbourne and CABI, Wallingford, pp. 123-138.

Bravo S., Erranz F., Lagos C. 2009: A comparison of sea lice, Caligus rogercresseyi, fecundity in four areas in southern Chile. J. Fish Dis. 32: 107-113.

Bravo S., Pozo V., Silva M.T., Abarca D. 2013: Comparison of the fecundity rate of Caligus rogercresseyi infesting Atlantic salmon (Salmo salar L.) on farms in two regions of Chile. Aquaculture 404: 55-58.

Chávez-Sánchez M.C., Alvarez-Lajonchère L., Abdo de la Parra M.I., García-Aguilar N. 2008: Advances in the culture of the Mexican bullseye puffer fish Sphoeroides annulatus, Jenyns (1842). Aquac. Res. 39: 718-730.

Costello M.J. 2006: Ecology of sea lice parasitic on farmed and wild fish. Trends Parasitol. 22: 475-483.

Costello, M.J. 2009. The global economic cost of sea lice to the salmonid farming industry. J. Fish Dis. 32: 115-118.

DoJiri M., Ho J.-S. 2013: Systematics of the Caligidae, copepods parasitic on marine fishes. Koninklijke Brill NV, Leiden, 448 pp.

Fajer-Ávila E.J., Martínez-Rodríguez I., Abdo de la Parra M.I., Álvarez-Lajonchere L., Betancourt-Lozano M.
2008: Effectiveness of freshwater treatment against Lepeophtheirus simplex (Copepoda: Caligidae) and Neobenedenia sp. (Monogenea: Capsalidae), skin parasites of bullseye puffer fish, Sphoeroides annulatus reared in tanks. Aquaculture 284: 277 280 .

González, L., Carvajal J. 2003: Life cycle of Caligus rogercresseyi, (Copepoda: Caligidae) parasite of Chilean reared salmonids. Aquaculture 220: 101-117.

González M.T., Molinet C., Arenas B., Asencio G., CarvaJAL J. 2012: Fecundity of the sea louse Caligus rogercresseyi on its native host Eleginops maclovinus captured near salmon farms in southern Chile. Aquac. Res. 43: 853-860.

Hamre L.A., Eichner C., Caipang C.M.A., Dalvin S.T., Bron J.E., Nilsen F., Boxshall G., Skern-Mauritzen R. 2013: The salmon louse Lepeophtheirus salmonis (Copepoda: Caligidae) life cycle has only two chalimus stages. PLoS ONE, 8: e73539.

Heuch P.A., Nordhagen J.R., Schram T.A. 2000: Egg production in the salmon louse (Lepeophtheirus salmonis (Krøyer)) in relation to origin and water temperature. Aquac. Res. 31: 801814.

Ho J.-S., Gómez S., Fajer-Avila E. 2001: Lepeophtheirus simplex sp. n., a caligid copepod (Siphonostomatoida) parasitic on "botete" (bullseye puffer, Sphoeroides annulatus) in Sinaloa, Mexico. Folia Parasitol. 48: 240-248.

Ho J.-S., LIN C.-L. 2004: Sea Lice of Taiwan (Copepoda: Caligidae). The Sueichan Press, Keelung, 388 pp.

Huys R., Boxshall G.A. 1991: Copepod Evolution. The Ray Society, London, 468 pp. 
Johnson S.C., Albright L.J. 1991a: The developmental stages of Lepeophtheirus salmonis (Krøyer, 1837) (Copepoda Caligidae). Can. J. Zool. 69: 929-950.

Johnson S.C., Albright L.J. 1991b: Development, growth, and survival of Lepeophtheirus salmonis (Copepoda: Caligidae) under laboratory conditions. J. Mar. Biol. Assoc. U.K. 71: 425-436.

Johnson S.C., Treasurer J.W., Bravo S., Nagasawa K., Kaвata Z. 2004: A review of the impact of parasitic copepods on marine aquaculture. Zool. Stud. 43: 229-243.

Lewis A.G. 1963: Life history of the caligid copepod Lepeophtheirus dissimulatus. Pac. Sci. 17: 195-242.

Lin C.-L., Ho J.-S. 1993: Life history of Caligus epidemicus Hewitt parasitic on tilapia (Oreochromis mossambicus) cultured in brackish water. In: G.A. Boxshall and D. Defaye (Eds.), Pathogens of Wild and Farmed Fish: Sea Lice. Ellis Horwood, Chichester, pp. 5-15.

Madinabeitia I., Nagasawa K. 2011: Chalimus stages of Caligus latigenitalis (Copepoda: Caligidae) parasitic on blackhead seabram from Japanese waters, with discussion of terminology used for developmental stages of caligids. J. Parasitol. 97: 221-236.

Morales-Serna F.N., Rubio-Godoy M., Gómez S. 2011: Seasonality of parasitic copepods on bullseye puffer, Sphoeroides annulatus (Pisces: Tetraodontidae), from the northwestern coast of Mexico. J. Parasitol. 97: 565-573.

Ohtsuka S., Takami I., Venmathi Maran B.A., Ogawa K., Shimono T., Fujita Y., Asakawa M., Boxshall G.A. 2009: Developmental stages and growth of Pseudocaligus fugu
Yamaguti, 1936 (Copepoda: Siphonostomatoida: Caligidae) host-specific to puffer. J. Nat. Hist. 43: 1779-1804.

Pike A.W., Wadsworth S.L. 1999: Sealice on salmonids: their biology and control. Adv. Parasitol. 44: 233-337.

Poulin R. 2007: Evolutionary Ecology of Parasites. Princeton University Press, New Jersey, 332 pp.

Ritchie G., Mordue A.J., Pike A.W., Rae H. 1993: The reproductive output of Lepeophtheirus salmonis adult females in relation to seasonal variability of temperature and photoperiod. In: G.A. Boxshall and D. Defaye (Eds.), Pathogens of Wild and Farmed Fish: Sea Lice. Ellis Horwood, Chichester, pp. 153-165.

Tully O. 1989: The succession of generations and growth of the caligid copepod Caligus elongatus and Lepeophtheirus salmonis parasitizing farmed Atlantic salmon smolts (Salmo salar L.). J. Mar. Biol. Assoc. U.K. 69: 279-287.

Tully O., Whelan K.F. 1993: Production of nauplii of Lepeophtheirus salmonis (Krøyer) (Copepoda: Caligidae) from farmed and wild salmon and its relation to the infestation of wild sea trout (Salmo trutta L.) off the west coast of Ireland in 1991. Fish. Res. 17: 187-200.

Venmathi Maran B.A., Moon S.Y., Ohtsuka S., Oh S.-Y., Soh H.Y., Myoung J.-G., Iglikowska A., Boxshall G.A. 2013: The caligid life cycle: new evidence from Lepeophtheirus elegans reconciles the cycles of Caligus and Lepeophtheirus (Copepoda: Caligidae). Parasite 20: 15.

Walter T.C., Boxshall G. 2014: World of Copepods database, www.marinespecies.org/copepoda, 4/2014

Cite this article as: Morales-Serna F.N., Rivas-Salas A.I., Gómez S., Fajer-Ávila E.J. 2015: Developmental stages and fecundity of Lepeophtheirus simplex (Copepoda: Caligidae) parasitic on bullseye puffer fish (Sphoeroides annulatus). Folia Parasitol. 62: 004. 